\title{
FRIT を用いた蒸気圧縮式冷凍機のデータ駆動型温度制御
}

\author{
鈴木 元哉 $a, b, *$
}

\section{Data-driven Temperature Control Based on FRIT for Refrigeration Systems}

\author{
Motoya Suzuki ${ }^{a, b, *}$
}

(Received April 21, 2021; revised June 1, 2021; accepted June 7, 2021)

\begin{abstract}
The study of refrigeration systems is attracted topics. Refrigeration is the generation of cooling to maintain a particular product or space at a temperature lower than the ambient temperature. For realizing good control performances, a model-free control is desired. However, a standard PID control may not realize good control performance since refrigeration systems have strong nonlinearity. In this study, we proposed a temperature control based on Fictitious reference feedback tuning(FRIT). The validity of the proposed method is verified through numerical simulation of PID Benchmark 2018.
\end{abstract}

キーワード : データ駆動制御, 冷凍機, 制御系設計, FRIT

Keywords : Data-driven control, refrigeration system, Control system design, FRIT.

\section{1.はじめに}

蒸気圧縮式冷凍機は 1 世紀以上も前から研究されてい る。蒸気圧縮式冷凍機とは，特定の製品や空間を環境の 温度より低い温度へ維持するための冷却システムである。 食品保存，化学・プロセス産業，製造プロセス，金属冷 蔵, 医薬品製造, 製水など, さまざまな用途へ応用され ている。現代技術の急速な進歩に伴い，蒸気圧縮式冷凍 機は商業ビルや住宅の空間冷却の最も一般的な手段とな っている。一方, エネルギー消費量の急激な増加等が問 題となり，エネルギー効率のよい温度制御が望まれる。

冷凍機の制御については, PID 制御(1), 非干渉制御(2), 最適制御(3-5)，モデル予測制御（MPC）(6-7)，ロバスト制御 (8-9), 等が報告されている。しかし, 蒸気圧縮式冷凍機は, 熱伝達プロセスに起因する強い非線形性を有する。プラ ントモデルを低次のシステムとして同定しても，モデル 誤差の影響にて制御系の性能が劣化することが考えられ

\footnotetext{
*Corresponding author. E-mail:m-suzuki@iaec.ac.jp, s2042009@edu.cc.uec.ac.jp

a (株)いす ゙゙中央研究所

干 252-0881 神奈川県藤沢市土棚 8

Isuzu advanced engineering center, Ltd.

8, Fujisawa-shi Tsuchidana, Kanagawa-ken 252-0881, Japan

b 電気通信大学 大学院情報理工学研究科

干182-8585 東京都調布市調布ヶ丘 1-5-1

Graduate School of Informatics and Engineering, The University of elector-communications.

1-5-1, Chofugaoka, Chofu, Tokyo 182-8585, Japan
}

る。また，時定数が非常に長いため，システム同定のた めの試験に膨大な工数が必要となってしまう。このよう な議論から, 蒸気圧縮式冷凍機にはPID 制御のような モデルフリーな制御が望まれている。

蒸気圧縮式冷凍機のプロセス制御ベンチマーク問題と して「Benchmark PID 2018」が報告されている(10)。この ベンチマーク問題では, 蒸気圧縮式冷凍機の詳細なプラ ントモデルが MATLAB/Simulink のパッケージとして提 供されている。IFAC 主催の国際会議として開催された「T he 2018 IFAC Conference on Advances in Proportional-In tegral-Derivative Control」では, このベンチマーク問題を 題材とした様々な制御方法が提案された(11-17)。提案され た方法の中でも, データ駆動型制御は制御器の設計に 1 回の実験しか必要としないという優れた点を有すること が知られている。先行研究では，データ駆動制御の代表 的な手法であるVirtual reference feedback tuning(VRFT) (18)を適用した事例が報告されている(17)。一回の開ループ 実験データを取得するだけで閉ループ応答を改善できる ことが報告されている。一方，VRFT だと開ループ実験 データ取得のため，冷凍機の制御を一時的に停止させな ければならない。冷凍機の時定数が長いため，実験デー 夕取得に長い時間を要してしまう。空調機向けの冷凍機 だと，温度制御が長時間停止してしまうため，空調の快 適性が損なわれる可能性がある。大規模プラント向けの 冷凍機だと，冷凍機の稼働停止による膨大なコストが懸 
念される。実用的な面から考えると，開ループ実験を必 要としない手法が望ましい。オンラインでPID ゲインを 更新できれば，冷凍機の稼働停止による諸問題を起こす ことなく，所望の制御応答を実現できる。

オンライン型データ駆動型制御法の一つとして, Fictitious Reference Feedback Tunings(FRIT) ${ }^{(19,20) を ヘ ゙ ー ス ~}$ としたデータ駆動型制御が提案されている。若佐らは, 標準的な FRIT と RLS のアルゴリズムを応用したオンラ インのデータ駆動制御(FRIT-RLS) を提案している(21)。制 御対象に強い非線形性がある場合や，大きな外乱が発生 した場合でも，所望の閉ループ忘答を得ることができる。 FRIT-RLS の応用として, 飛行体(22), 車両(23), トランス ミッション(24)等のさまざまな非線形システムへの適用 事例が報告されている。蒸気圧縮式冷凍機へFRIT-RLSを ベースとした温度制御を適用すれば，良好な制御性能が 得られる可能性がある。オンラインで PID ゲインを更新 できるため, 開ループ実験による冷凍機の稼働停止によ る諸問題を起こすこともないと考えられる。

本研究では, FRIT-RLS を用いた蒸気圧縮式冷凍機の温 度制御系を設計した。提案手法をベンチマーク問題へ適 用し, 提案手法の有効性を検証した。本稿では提案手法 および有効性検証の結果を報告する。

$$
\text { 2. ベンチマーク問題 }
$$

ここでは，Benchmark PID 2018(10)の概要を説明する。 蒸気圧縮式冷凍機の概略図を図 1 に示す。蒸気圧縮式冷 凍機は, 1)蒸発器, 2) 凝縮器, 3) 可変速圧縮機, 4)膨張弁, から構成される。冷凍機の冷却メカニズムは, 蒸発器の 二次側から熱を取り除き，その熱を凝縮器の二次側に移 して熱を放出することである。冷凍機の冷媒は以下の手 順にて冷凍機を循環する。

a) 低温・高圧の冷媒が蒸発器へ取り込まれ, 蒸発器二次 側の熱を奪いながら蒸発する。

b）高圧・高温の冷媒が圧縮機に取り込まれ，凝縮器に入

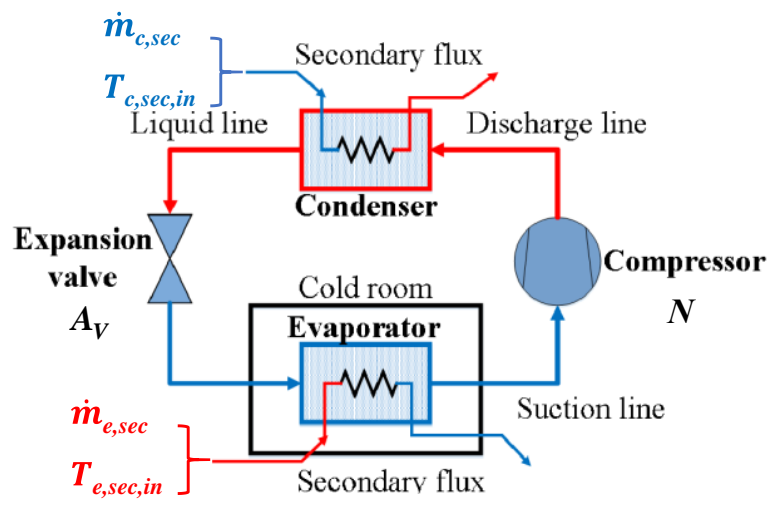

Fig. 1. Refrigeration systems ${ }^{(10)}$.
る。

c）凝縮された冷媒が過冷却され, 凝縮器の二次側へ熱を 放出する。

d）低圧・低温度の冷媒が膨張弁によって高圧・低温にな り, 蒸発器へ取り込まれる。

本ベンチマーク問題では, 冷凍サイクルにおける外乱 を表 1 のように定義している。本システムの目的は表 1 の外乱条件下において, 蒸発器二次側の出口温度 $T_{e, \text { sec, out }}$ を設定温度へ保持することである。蒸発器の出口温度へ の主要な外乱として, 冷凍サイクルにおける質量流束 $m_{c, s e c}$ および二次質量流束 $m_{c, s e c}$ が挙げられる。また, 本 システムでは, 凝縮器二次側の入口温度 $T_{c, s e c, i n}$, と蒸発 器二次側の入口温度 $T_{e, s e c, \text { in }}$ 外乱として扱われる。冷凍 機では，なるべく電力効率よく設定温度を維持すること が望ましい, 電力効率のよい運転を実現するため, 蒸発 器の出口温度だけでなく過熱度 $T_{S H}$ も制御する必要があ る。つまり, 冷凍機における制御目的は以下のような多 入出力系の制御問題として与えられる。

- 問題

圧縮機回転数 $N$ と膨張弁開度 $A_{v}$ を制御入力とし, 蒸発 器二次側の出口温度 $T_{e, s e c, \text { out }}$ と過熱度 $T_{S H}$ を出力とするシ ステムを考える。表 1 の外乱が存在する条件下にて, $T_{e, s e c, \text { out }}$ と $T_{S H}$ ができるだけエネルギー効率よく目標值へ 追従するような制御測を考えよ。

Benchmark PID 2018 では, 温度制御系の初期制御器も 提供されている。初期制御器は, 離散時間制御器と PI 制 御で構成される。ここで, 制御信号と出力信号を

$$
\begin{gathered}
u_{1}(k) \triangleq A_{v} \\
u_{2}(k) \triangleq N \\
y_{1}(k) \triangleq T_{e, s e c, \text { out }} \\
y_{2}(k) \triangleq T_{S H} \\
r_{1}(k) \triangleq R e f_{-} T_{e, s e c, \text { out }} \\
r_{2}(k) \triangleq R e f_{-} T_{S H}
\end{gathered}
$$

と定義した。ベンチマーク問題における初期制御則は

$$
u_{i}(k)=C^{r}{ }_{i}(q)\left(r_{i}(k)-y_{i}(k)\right)
$$

と与えられてる。ここで， $i_{(i=1,2)}$ はインデックスである。 ベンチマーク問題における初期制御器 $C^{r}{ }_{i}$ は

$$
\begin{gathered}
C^{r}{ }_{1}(q)=\frac{-1.0136 q^{2}-0.0626 q+0.9988}{(q-1)(q-0.9853)} \\
C^{r}{ }_{2}(q)=\frac{0.42 q-0.02}{(q-1)}
\end{gathered}
$$

と与えられている。本稿では，初期制御器よりも良好な 制御応答を実現可能な制御系の設計を目指す。次節にて この課題を解決可能な温度制御系設計を設計する。

3. FRITを用いたデータ駆動型温度制御 本稿では, 開ループ実験を必要としないオンライン型 
のデータ駆動型温度制御系を設計する。本制御系は PI 制 御器と FRIT-RLS による更新則から構成される。

\subsection{PI 制御器}

図 2 に温度制御系のブロック図を示す。ここでは, $T_{e, s e c, o u t}$ と $T_{S H}$ を独立なフィードバックループにて制御す る。各ループの制御則を

$$
u_{i}(k)=C^{F B}{ }_{i}(q)\left(r_{i}(k)-y_{i}(k)\right)
$$

とした。ここで, 制御器 $C^{F B_{i}}$ を可調整パラメータ $\rho_{i}$ でパ ラメタライズされた PI 制御器

$$
C_{i}^{F B}\left(q, \rho_{i}\right)=\rho_{i}^{T} \varphi(q)=\left[\begin{array}{ll}
k_{i}{ }^{P} & k_{i}{ }^{I}
\end{array}\right]\left[\begin{array}{c}
1 \\
\frac{1}{q-1}
\end{array}\right]
$$

とした。本稿の制御系では, 可調整パラメータ $\rho_{i}$ を後述 の FRIT-RLS にてリアルタイム更新する。

\subsection{FRIT}

標準的な FRIT(20)の基本的な考え方を説明する。FRIT では, 目標值 $r_{i}$ から制御変数 $y_{i}$ までの規範モデル $T_{i}(q)$ が あらかじめ与えられているとする。まず, 閉ループ実験 にてデータ長 $N$ の入出力データを得る。次に, 閉ループ 系の擬似参照信号を

$$
\tilde{r}_{i}\left(k, \rho_{i}\right)=C_{i}{ }^{F B}\left(q, \rho_{i}\right)^{-1} u_{i}(k)+y_{i}(k)
$$

と計算する。ここで, FRIT の評価関数を

$$
J_{i}\left(\rho_{i}\right)=\sum_{k=0}^{N}\left(y_{i}(k)-T_{i}(q) \tilde{r}_{i}\left(k, \rho_{i}\right)\right)
$$

と定義する。この評価関数は, 閉ループ伝達関数と規範 モデルの相対誤差を最小化することに等しい。したがっ て, 評価関数を最小化できれば所望の制御応答を実現で きる。一方, 実験データに外乱信号が含まれている場合, 所望の制御性能を実現できないとされる(19)。また，制御 対象が強い非線形性を有する場合，所望の制御応答を実 現できない可能性が指摘されている(25)。そこで, 本稿の 温度制御系では, 通常の FRIT でなくFRIT-RLS を用いて 可調整パラメータ $\rho_{i}$ をオンラインで更新する。

\subsection{FRIT-RLS}

FRIT-RLS ${ }^{(21)}$ では，FRIT の評価関数を線形最適化問題 に置き換え, Recursive least square(RLS)法によって評価関 数を最小化する。まず, FRIT の評価関数がゼロとなるケ 一スなケースを考えると，

$$
y_{i}(k)-T_{i}(q) \tilde{r}_{i}\left(k, \rho_{i}\right)=0
$$

が成り立つ。式(14)を式(13)へ代入すると,

$$
C_{i}^{F B}\left(q, \rho_{i}\right)\left(1-T_{i}(q)\right) y_{i}(k)-T_{i}(q) u_{i}(k)=0
$$

が成り立つ。式(15)から擬似誤差信号

$$
\tilde{e}_{i}\left(k, \rho_{i}\right)=C_{i}^{F B}\left(q, \rho_{i}\right)\left(1-T_{i}(q)\right) y_{i}-T_{i}(q) u_{i}(k)
$$

\begin{tabular}{|c|c|c|}
\hline Disturbance & $\begin{array}{c}\text { Mathematical } \\
\text { symbol }\end{array}$ & Units \\
\hline $\begin{array}{l}\text { Inlet temperature of the condenser } \\
\text { secondary flux }\end{array}$ & $T_{c, s e c, i n}$ & ${ }^{\circ} \mathrm{C}$ \\
\hline $\begin{array}{l}\text { Mass flow of the condenser } \\
\text { secondary flux }\end{array}$ & $m_{c, \sec }$ & $\mathrm{g} \cdot \mathrm{s}^{-1}$ \\
\hline $\begin{array}{l}\text { Inlet pressure of the condenser } \\
\text { secondary flux }\end{array}$ & $P_{c, s e c}$ & bar \\
\hline $\begin{array}{l}\text { Inlet temperature of the evaporator } \\
\text { secondary flux }\end{array}$ & $T_{e, s e c, i n}$ & ${ }^{\circ} \mathrm{C}$ \\
\hline $\begin{array}{l}\text { Mass flow of the evaporator } \\
\text { secondary flux }\end{array}$ & $m_{e, s e c}$ & bar \\
\hline $\begin{array}{l}\text { Inlet pressure of the evaporator } \\
\text { secondary flux }\end{array}$ & $P_{e, s e c}$ & $g \cdot \mathrm{s}^{-1}$ \\
\hline $\begin{array}{c}\text { Compressor surroundings } \\
\text { temperature }\end{array}$ & $T_{\text {surr }}$ & ${ }^{\circ} \mathrm{C}$ \\
\hline
\end{tabular}

を定義する。ここで, 変数 $d_{i}$ と $\gamma_{i}$ を

$$
\begin{gathered}
d_{i}(k)=T_{i}(q) u_{i}(k) \\
\gamma_{i}(k)=\varphi(q)\left(1-T_{i}(q)\right) y_{i}(k)
\end{gathered}
$$

と定義する。式(17)と式(18)を(16)式に代入し，擬似誤差
Table 1. Disturbance.

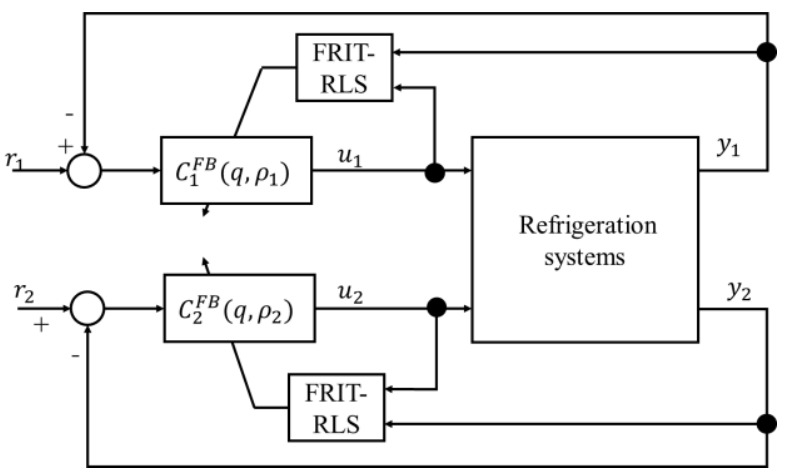

Fig. 2. Block diagram of temperature control

信号を

$$
\tilde{e}_{i}\left(k, \rho_{i}\right)=\rho_{i}{ }^{T} \gamma_{i}-d_{i}
$$

と再定義する。式(19)は可調整パラメータ $\rho_{i}$ に対して線 形である。したがって, 最小二乗法によるリアルタイム の最小化を実現できる。本稿では, 忘却係数付きの RLS にて疑似誤差信号を最小化する。忘却係数付きの RLS ア ルゴリズムは,

$$
\begin{gathered}
h_{i}(k)=\frac{Q_{i}(k-1) \gamma_{i}(k)}{\lambda+\gamma_{i}^{T}(k) Q_{i}(k-1) \gamma_{i}(k)} \\
Q_{i}(k)=\frac{Q_{i}(k-1)-h_{i}(k)\left(\gamma_{i}^{T}(k) Q_{i}(k-1)\right)}{\lambda} \\
\hat{\rho}_{i}(k)=\hat{\rho}_{i}(k-1)+\hat{\rho}_{i}(k)\left(d_{i}(k)\right. \\
\left.-\gamma_{i}^{T}(k) \hat{\rho}_{i}(k-1)\right)
\end{gathered}
$$

となる。ここで, $Q_{i}$ が相関行列, $\lambda$ が忘却係数, $\hat{\rho}_{i}$ が更新 パラメータである。ただし，更新パラメータをそのまま 閉ループ系へ実装してしまうと, パラメータの急激な変 更によるシステムの不安定化が懸念される。そこで，フ 
イードバック補償器の可調整パラメータを

$$
\rho_{i}(k)=\beta \hat{\rho}_{i}(k-1)+(1-\beta) \rho_{i}(k-1)
$$

と更新する。ここで $\beta$ は 1 以下の正の数である。式(23) に基づいて可調整パラメータを更新することにより，可 調整パラメータの急激な変化を抑制できる。

以上の手順にて, 開ループ実験のために制御系を停止 させることなく，所望の制御応答を実現できる。

$$
\text { 4. 数值シミュレーション }
$$

本節で, 数值シミュレーションにて提案手法の有効性 を検証する。ここでは, Benchmark PID 2018 にて提供さ れている MATLAB/Simulink のシミュレーションモデル を用いて数值シミュレーションした。

\section{1 冷凍機の動作条件}

本節では，ベンチマーク問題における冷凍機の運転条 件を示す。表 2 に Benchmark PID 2018 における冷凍機の 動作点を示す。また, 凝縮器と蒸発器の二次側の入り口 温度を図 3 に示す。出口温度と加熱温度の目標值を図 4 に示す。本シミュレーションは, 表 2 の定常状態から温 度制御を開始する。ここで, 圧縮機回転数と膨張弁開度 のレンジが $A_{v} \in[10-100] \%, N \in[30-50] \mathrm{Hz}$ として設定さ れている。出口温度の目標值 $\operatorname{Ref} T_{e, \text { sec, out }}$ は- $0.5{ }^{\circ} \mathrm{C}$ ステ ップ信号として設定されている。また，時刻 $540 \mathrm{~s} に て ~ T_{e}$, $s e c$, in が- $1{ }^{\circ} \mathrm{C}$ 変化する。また, $\mathrm{t}=960$ 秒の時刻にて $T_{e, ~ s e c}$, in と $T_{c, s e c, \text { in }}$ にそれぞれ $1{ }^{\circ} \mathrm{C}$ と $-3{ }^{\circ} \mathrm{C}$ 変化する。

4.2 シミュレーション条件

本節では本シミュレーションにおける制御系の条件を 示す。本シミュレーションでは，規範モデルを

$$
T_{1}(q)=T_{2}(q)=\frac{0.6321}{q-0.3679}
$$

と設定した。また, 初期の PI ゲインを $k_{1}{ }^{P}=-20.4958, k_{1}{ }^{I}=-$ 7.0480, $k_{2}{ }^{P}=12.8927, k_{2}{ }^{I}=0.3093$ として設定した。FRIT-RLS のパラメータを $\lambda=0.998, \beta=0.8$ とした。ここで, 初期相 関行列を

$$
Q_{1}(0)=Q_{2}(0)=\left[\begin{array}{cc}
100 & 0 \\
0 & 100
\end{array}\right]
$$

とした。

本シミュレーションでは, ベンチマーク問題用の MATLAB/Simulinkにて制御器を実装し, サンプル時間を $1 \mathrm{~s}$ の設定でシミュレーションした。

\section{3 シミュレーション結果}

図 5 に出口温度と過熱度の制御結果示す。図 6 に膨張 弁開度と圧縮機回転数を示す。青線が初期制御器の制御 結果, 赤線が固定ゲインのPI 制御における制御結果, 黄 線が FRIT-RLS の温度制御系を適用した結果, 点線が目 標值である。また, 図 7 に可調整パラメータの時系列デ ータを示す。固定ゲインの PI 制御では, FRIT-RLS の初 期 PI ゲインが設定されている。FRIT-RLS の温度制御系
を適用した結果, 過熱度と出口温度が目標值へ追従して いることがわかる。過熱度と出口温度の応答が規範モデ ルの応答へ近づいたため, 目標值への速応性が向上した ことがわかる。また，外乱への抑圧性も向上しているこ とが明らかである。可調整パラメータが逐次更新され, 目標值への速応性と外乱抑圧性が改善されたと考えられ る。一方, 時刻 $540 \mathrm{~s}$ にてオーバーシュートが発生して いることがわかる。ワインドアップ現象により，この区 間のみ制御精度が劣化したと考えれる。本結果から FRIT-

\begin{tabular}{|c|c|c|c|}
\hline Description & Variable & Value & Units \\
\hline Expansion valve opening & $A_{v}$ & 48.79 & $\%$ \\
\hline Compression speed & $N$ & 36.45 & $\mathrm{H}$ \\
\hline $\begin{array}{l}\text { Outlet temperature of the } \\
\text { evaporator second flux }\end{array}$ & $T_{e, s e c, \text { out }}$ & -22.15 & ${ }^{\circ} \mathrm{C}$ \\
\hline Degree of superheating & $T_{S H}$ & 14.65 & ${ }^{\circ} \mathrm{C}$ \\
\hline $\begin{array}{l}\text { Inlet temperature of the } \\
\text { condenser secondary flux }\end{array}$ & $T_{c, \text { sec, in }}$ & 30 & ${ }^{\circ} \mathrm{C}$ \\
\hline $\begin{array}{c}\text { Mass flow of the condenser } \\
\text { secondary flux }\end{array}$ & $m_{c, s e c}$ & 150 & $g \cdot \mathrm{s}^{-1}$ \\
\hline $\begin{array}{l}\text { Inlet pressure of the condenser } \\
\text { secondary flux }\end{array}$ & $P_{c, \text { sec }, \text { in }}$ & 1 & bar \\
\hline $\begin{array}{l}\text { Inlet temperature of the } \\
\text { evaporator second flux }\end{array}$ & $T_{e, s e c, \text { in }}$ & -20 & ${ }^{\circ} \mathrm{C}$ \\
\hline $\begin{array}{l}\text { Mass flow of the condenser } \\
\text { secondary flux }\end{array}$ & $m_{e, s e c}$ & 150 & $g \cdot s^{-1}$ \\
\hline $\begin{array}{l}\text { Inlet pressure of the evaporator } \\
\text { secondary flux }\end{array}$ & $P_{e, \text { sec }, \text { in }}$ & 1 & bar \\
\hline $\begin{array}{c}\text { Compressor surroundings } \\
\text { temperature }\end{array}$ & $T_{\text {surr }}$ & 25 & ${ }^{\circ} \mathrm{C}$ \\
\hline
\end{tabular}
RLS を用いた温度制御系を適用することにより，外乱抑 圧性と目標值への速応性を改善できることを確認できた。

Table 2. Simulation condition.
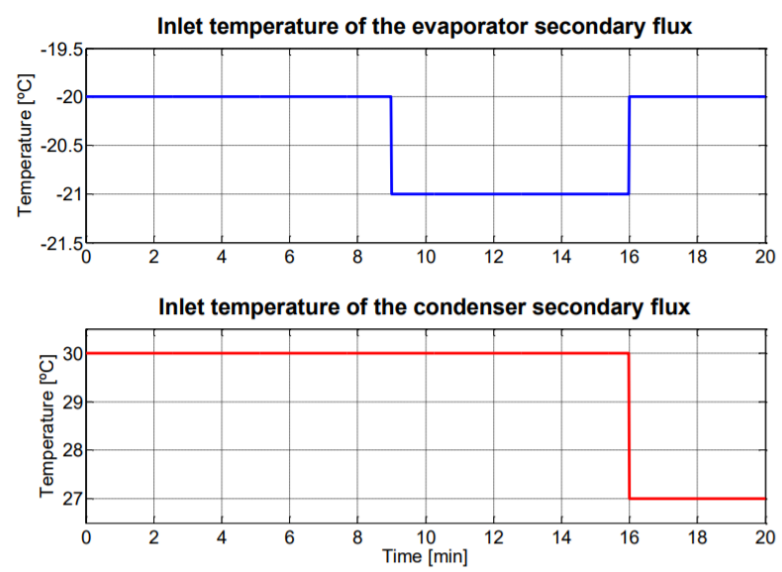

Fig. 3. Disturbance signals. 

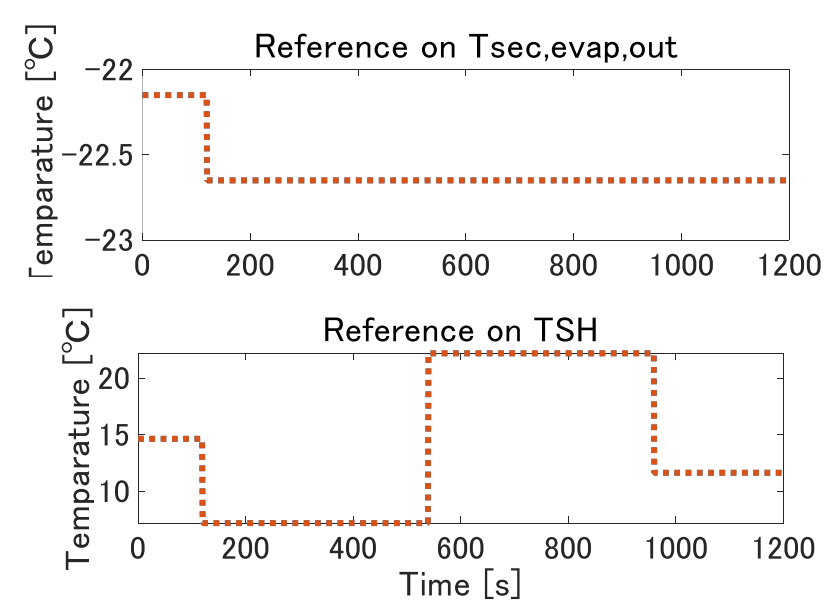

Fig. 4. Reference signals

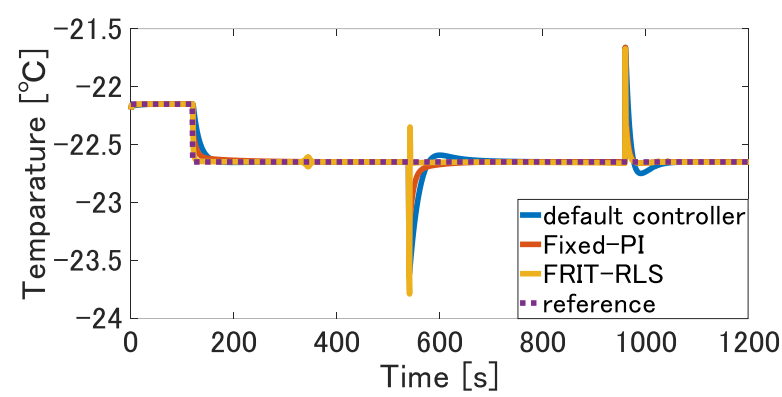

(a) Outlet temperature of the evaporator second flux.

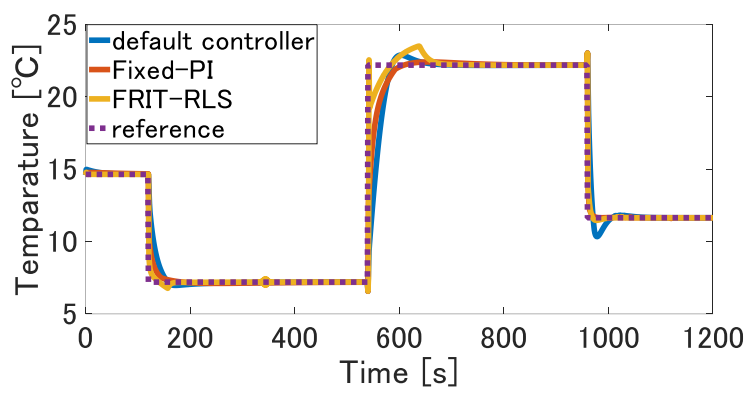

(b) Degree of superheating.

Fig. 5. Output signals.

\section{4 絶対誤差積分による性能評価}

PID Benchmark 2018 の性能評価指標を適用し，提案手 法の有効性を定量的に分析する。PID Benchmark 2018 で は，以下の 8 つの指標に基づき二つの制御系の性能を比 較する。

$$
\begin{gathered}
I A E_{i}=\int_{0}^{t}\left|e_{i}(t)\right| d t \\
\operatorname{ITAE}_{i}=\int_{t_{c}}^{t_{c}+t_{s}}\left(t-t_{c}\right)\left|e_{i}(t)\right| d t \\
\operatorname{RIAE}_{i}\left(C_{2}, C_{1}\right)=\frac{I A E_{i}\left(C_{2}\right)}{I A E_{i}\left(C_{1}\right)} \\
\operatorname{IAVU}_{i}=\int_{0}^{t}\left|\frac{d u_{i}(t)}{d t}\right| d t
\end{gathered}
$$

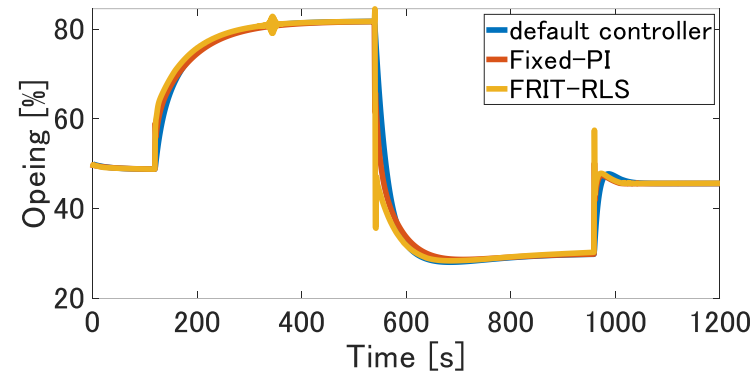

(a) Valve opening [\%].

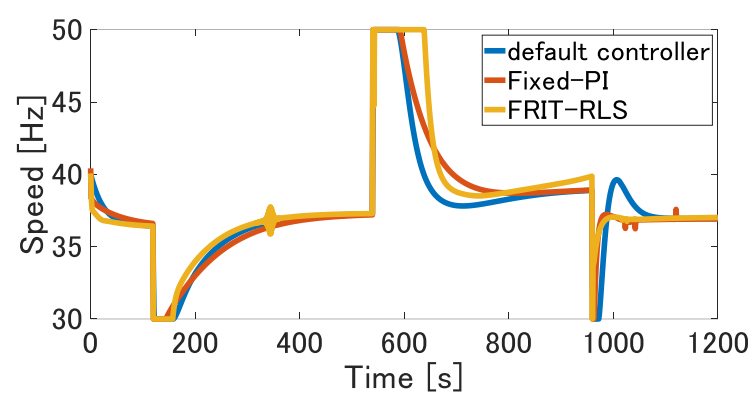

(b) Compressor speed $[\mathrm{Hz}]$.

Fig. 6. Control signals.

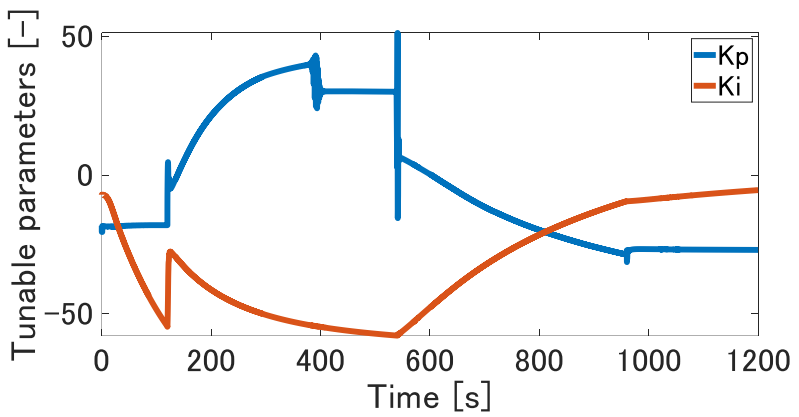

(a) Tunable parameters $\rho_{I}$.

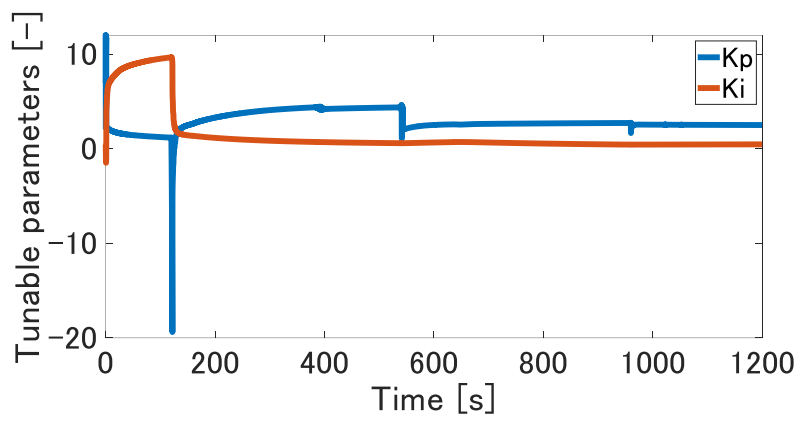

(b) Tunable parameters $\rho_{2}$.

Fig. 7. Tunable parameters with FRIT-RLS,

$$
\begin{aligned}
\operatorname{RIAVU}_{i}\left(C_{2}, C_{1}\right) & =\frac{\operatorname{IAE} E_{i}\left(C_{2}\right)}{\operatorname{IAE} E_{i}\left(C_{1}\right)} \\
\operatorname{RITAE}_{i}\left(C_{2}, C_{1}, t_{c}, t_{s}\right) & =\frac{\operatorname{ITAE} E_{i}\left(C_{2}, t_{c}, t_{s}\right)}{\operatorname{ITAE} E_{i}\left(C_{1}, t_{c}, t_{s}\right)} \\
\operatorname{RITVU}_{i}\left(C_{2}, C_{1}\right) & =\frac{\operatorname{IAV} U_{i}\left(C_{2}\right)}{\operatorname{IAVU}\left(C_{1}\right)}
\end{aligned}
$$


Table 3. Evaluation results.

\begin{tabular}{|c|c|c|}
\hline Index & $\begin{array}{c}\text { Default VS } \\
\text { fixed PI }\end{array}$ & $\begin{array}{c}\text { Default VS } \\
\text { FRIT-RLS }\end{array}$ \\
\hline $\operatorname{RIAE}_{1}\left(C_{2}, C_{1}\right)$ & 0.4820 & 0.2543 \\
\hline $\operatorname{RIAE}_{2}\left(C_{2}, C_{1}\right)$ & 0.5885 & 0.4246 \\
\hline $\operatorname{RITAE}_{1}\left(C_{2}, C_{1}, t_{c 1}, t_{s 1}\right)$ & 2.6779 & 1.3550 \\
\hline $\operatorname{RITAE}_{2}\left(C_{2}, C_{1}, t_{c 2}, t_{s 2}\right)$ & 1.2333 & 0.4134 \\
\hline $\operatorname{RITAE}_{2}\left(C_{2}, C_{1}, t_{c 3}, t_{s 3}\right)$ & 1.0103 & 1.1125 \\
\hline $\operatorname{RITAE}_{2}\left(C_{2}, C_{1}, t_{c 4}, t_{s 4}\right)$ & 0.1095 & 0.1559 \\
\hline$R I A V U_{1}\left(C_{2}, C_{1}\right)$ & 1.2786 & 1.8918 \\
\hline$R I A V U_{2}\left(C_{2}, C_{1}\right)$ & 0.9837 & 1.4122 \\
\hline$J\left(C_{2}, C_{1}\right)$ & 1.1512 & 0.7433 \\
\hline
\end{tabular}

$$
J\left(C_{2}, C_{1}\right)=\frac{\operatorname{IAVU} U_{i}\left(C_{2}\right)}{I A V U_{i}\left(C_{1}\right)}
$$

$C_{1}$ と $C_{2}$ は比較対象の制御系である。 RIAE は二つの制御 結果における積算絶対誤差（IAE）の比である。 RITAE は積分時間乗算絶対誤差 IT AEの比である。RIAV と RIAV $\mathrm{U}$ は, 制御入力の効率評価である。式(33)の $J$ は各評価指 標の平均值として算出される制御結果の総合的な指標で ある。したがって, 総合評価 $J$ が 1 より小さいほど, $C_{2}$ の方が $C_{1}$ よりも性能が向上していることがわかる。ここ では，固定ゲインの PI 制御と FRIT-RLS の温度制御系が ベンチマーク問題の初期制御器からどの程度性能向上し たかを評価する。表 3 に各制御器の比較結果を示す。表 3 は, 初期制御器を $C_{1}, \quad$ PI 制御とFRIT-RLS を $C_{2}$ とし た場合の比較結果である。固定のPI 制御を適用した結 果だと, 総合評価が 1.1512 となった。不適当なゲインを 設定したため，RITAE が大幅に悪化しまい，総合評価が 悪化したと考えられる。FRIT-RLS を適用した結果だと, 総合評価 $J$ が 0.7433 となった。初期の PI ゲインが不適 当でもオンライン更新より, 所望の応答特性が実現され, 総合評価が改善したと考えられる。

\section{5.おおりに}

本研究では, 冷凍機のための温度制御として FRIT-RLS を用いた PI コントローラを提案した。提案手法をベンチ マーク問題へ適用し，良好な制御性能を実現した。初期 制御器や固定 PI 制御器と比較して, 総合指数 J を改善で きた。本手法は開ループ実験を必要としない。したがっ て, 冷凍機停止に起因する諸問題を引き起こすことなく, 所望の制御応答を実現できる。一方, FRIT-RLS の制御結 果だと, 入力飽和の影響でオーバーシュートが発生する ことが確認された。今後の課題として, 入力飽和の影響 を抑制可能な制御系の設計が考えられる。
文献

(1) M. Salazar and F. Méndez, :"PID control for a single-stage transc ritical CO2 refrigeration cycle", Appl. Therm. Eng., Vol. 67, No. 12, pp. 429-438, 2014.

(2) Y. Shen, W.-J. Cai, and S. Li, :"Normalized decoupling control fo $\mathrm{r}$ highdimensional MIMO processes for application in room temper ature control HVAC systems", Control Eng. Pract., Vol. 18, No. 6, pp. 652-664, 2010.

(3) L. C. Schurt, C. J. L. Hermes, and A. T. Neto, :"A model-driven multivariable controller for vapor compression refrigeration system s”, Int. J. Refrig., Vol. 32, No. 7, pp. 1672-1682, 2009

(4) D. Leducq, J. Guilpart, and G. Trystram,: "Nonlinear predictive c ontrol of a vapour compression cycle", Int. J. Refrig., Vol. 29, N o.5, pp. 761-772, 2006.

(5) N. Jain and A. Alleyne, "Exergy-based optimal control of a vapor compression system”, Energy Convers. Manage., Vol. 92, pp. 353 $-365,2015$.

(6) T. G. Hovgaard, L. F. S. Larsen, K. Edlund, and J. B. Jørgensen, : "Model predictive control technologies for efficient and flexible power consumption in refrigeration systems", Energy, Vol. 44, pp. $105-116,2012$

(7) A. Afram and F. Janabi-Sharifi,: “Theory and applications of HVA C control systems-A review of model predictive control (MPC), Building Environ", Vol. 72, pp. 343-355, 2014.

(8) T. Sung, Y. J. Kim, H. S. Kim, and J. Kim :"Empirical modeling and robust control of a novel meso-scale vapor compression refrig eration system (mVCRS)”, Int. J. Refri, Vol. 77, pp.99-115, 2017.

(9) G. Bejarano, J. A. Alfaya, M. G. Ortega, and F. R. Rubio,: “Mul tivariable analysis and $\mathrm{H}_{\infty}$ control of a one-stage refrigeration cyc le", Appl. Therm. Eng., Vol. 91, No. 6, pp.1156-1167, 2015.

(10) G. Bejarano, J. A. Alfaya, D. Rodríguez, F. Morilla, and M. G. Ortega, : "Benchmark for PID control of refrigeration systems bas ed on vapour compression", IFAC-PapersOnLine, Vol. 51, No.4, p p. 497-502, 2018

(11) J. D.Rojas, F.Morilla, R.Vilanova, : "Multivariable PI control for a boiler plant benchmark using the virtual reference feedback tuni ng”. IFAC Proceedings Volumes, Vol.45, No.3, pp.376-381, 2012.

(12) R.Cajo, S.Zhao, C. M.Ionescu, R.De Keyser, D.Plaza, S.Liu, : "I MC based PID Control Applied to the Benchmark PID18.", IFACPapersOnLine, Vol.51, No. 4, pp.728-732, 2018.

(13) G. J. A.Soto, J. M. G.López, J. A.Hernández-Riveros, : "Coupled eVolutionary tuning of PID Controllers for the Benchmark on Vap or Compression Refrigeration”, IFAC-PapersOnLine, Vol.51, No.4, $\mathrm{p}$ p.509-514, 2018.

(14) C.Chen, J.Lu, : "Design of self-tuning SISO partial-form model-fr ee adaptive controller for vapor-compression refrigeration syste m”, IEEE Access, Vol.7, pp.125771-125782, 2019. 
(15) Y.Zhao, Y.Li, S.Dehghan, Y.Chen, : "Learning feedforward control of a one-stage refrigeration system", IEEE Access, Vol.7, pp.64120 $-64126,2019$.

(16) D. D.Huff, G. R. G.da Silva, L.Campestrini, : "Data-Driven contr ol design by prediction error identification for a refrigeration syst em based on vapor compression", IFAC-PapersOnLine, Vol.51, No.4, pp.704-709, 2018.

(17) V.BordigNo..n, L.Campestrini, : “Application of Multivariable Virt ual Reference Feedback Tuning with Anti-Windup to the Benchma rk PID 2018". IFAC-PapersOnLine, Vol.51, No.4, pp.515-520, 2018.

(18) M. C. Campi, A.Lecchini, S. M. Savaresi, : "Virtual reference fee dback tuning: a direct method for the design of feedback controll ers". Automatica, Vol.38, No.8, pp.1337-1346, 2002.

（19）相馬将太郎，金子修，藤井隆雄：「一回の実験データに基づく制御 器パラメータチューニングの新しいアプローチ Fictitious Reference Iterative Tuning の提案」. システム制御情報学会論文 誌, Vol.17, No.12, pp.528-536, 2004.

(20) O.Kaneko, : "Data-driven controller tuning: FRIT approach", IFAC Proceedings Volumes, Vol.46, No. 11, pp.326-336, 2013.

(21) Y.Wakasa, K.Tanaka, Y.Nishimura: "Online controller tuning via FRIT and recursive least-squares”, IFAC Proceedings Volumes, Vol.45, No.3, pp.76-80. 2012

(22) H.Endo, R.Aramaki, K.Sekiguchi, K.Nonaka, :“Application of model error compensator based on FRIT to quadcopter", In 2017 IEEE Conference on Control Technology and Applications (CCTA), pp. 20882093, 2017.

(23) 遠藤弘彬, 関口和真, 野中謙一郎: 「モデル誤差補償器のオンライ ン調整法」，計測自動制御学会論文集，Vol.55, No.3, pp.156-163, 2019.

(24) S.Yahagi, I.Kajiwara, T.Shimozawa, :"Slip control during inertia phase of clutch-to-clutch shift using model-free self-tuning proportionalintegral-derivative control", Proceedings of the Institutite of Mechanical Engineers, Part D: Journal of Automobile Engineering, 0954407020907257,2020

（25）遠藤祐甫, 大月智史, 岡本鷹文, 古賀毅, 中島健一: 「非線形性を 有する自動操船システムへの FRIT 適用」. システム制御情報学会 論文誌, Vol.33, No.8, pp.242-249, 2020 .

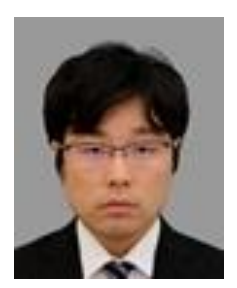

鈴木 元哉

2016 年 東京電機大学未来学部ロボット・メカト ロニクス学科卒業。2018 年東京電機大学未来科学 研究科ロボット・メカトロニクス学専攻修了。2018 年から 2019 年まで三菱電機株式会社勤務。2019 年 東京電機大学にて博士(工学)取得。2019年 株式会 社いすら゙中央研究所 研究員。2020 年 電気通信大 学 情報理工学研究科 機械知能システム学専攻。 博士(工学)。制御理論および応用の研究に従事。 